\section{Project-based Community of Inquiry for Effective Online Graduate Course on Life Cycle Assessment}

\author{
Peng Yen Liew ${ }^{a}$, Lian See Tana, Chan Choong Foong ${ }^{b}$, \\ Nor Ruwaida Jamiana \\ aMalaysia-Japan International Institute of Technology (MJIIT), \\ Universiti Teknologi Malaysia, Jalan Sultan Yahya Petra, 54100 Kuala \\ Lumpur, Malaysia \\ ${ }^{b}$ Medical Education and Research Development Unit, Faculty of Medicine, \\ University of Malaya, Kuala Lumpur, Malaysia \\ *pyliew@utm.my
}

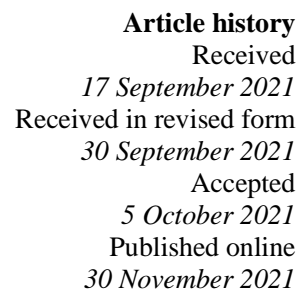

30 November 2021

\begin{abstract}
This article aimed to present the improvements on the instructional design of a postgraduate course, namely Life Cycle Assessment (LCA), for effective content delivery in online teaching and learning due to COVID-19 pandemic. The community of inquiry framework was used as the basis for this improvement. It was aided by project-based learning to enhance the educational experiences and improve content delivery efficiency. Conventional active learning teaching pedagogy was maintained in the early part of the course. Next, an open-ended project became the pillar of the second part of the course for performing a comparative LCA in a team. To ensure all students have high individual accountability, each team member performed a LCA study independently for a sub-scope of the project. Meanwhile, their teammates supported each other as each sub-scope is interdependent on the project. WhatsApp was used to promote interactions between students-students and students-instructors to provide just-in-time feedback, and weekly consultations were offered to students to monitor student progress. Based on the course evaluation, the students felt optimistic about the changes. They agreed that these new delivery methods helped them in mastering the subject matter.
\end{abstract}

Keywords: Community of Inquiry; Project-based Learning; Online Learning.

\section{Introduction}

The COVID-19 pandemic has catalysed online teaching and learning practices in higher education institutions around the world (Adnan \& Anwar, 2020; Chakraborty, Mittal, Gupta, Yadav, \& Arora, 2021). Due to national lockdown, online classes replace physical classes through synchronous and asynchronous learning. As a result, the learning management system and telecommunication apps become essential tools for sustaining the online teaching and learning practices (Mishra, Gupta, \& Shree, 2020).

\section{Literature}

The Community of Inquiry (CoI) framework is an established framework for planning online educational experiences (Garrison, Anderson, \& Archer, 1999). "Presence" is vital in the framework to engage learners in sustaining their concentration, which includes cognitive, social, and teaching presences (Garrison \& Arbaugh, 2007) (Figure 1). Arbaugh, Bangert, and Cleveland-Innes (2010) found that student perceptions support the CoI framework usage in online teaching and learning practices.

Cognitive presence is defined as knowledge construction through continuous communications in the learning environment (Stewart, 2019). Cognitive presence involves four stages in inquiry-based learning, which are (1) triggering event, usually a problem or learning issue to be explored by learners, (2) exploration, where the learners explore the problem or issue individually or in a team, (3) integration, in which the learners bring together information from the previous stage to construct their knowledge, and (4) resolution, in which the learners apply newly gained knowledge in the context of the subject matter (Garrison \& Arbaugh, 2007).

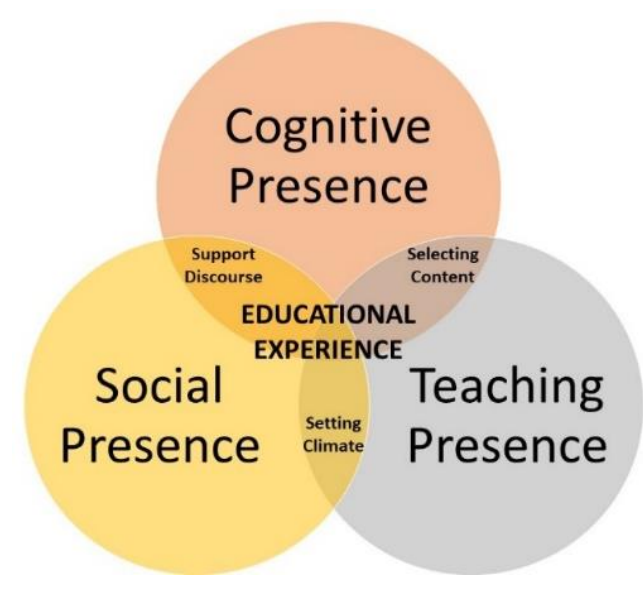

Figure 1. Community of Inquiry Model (Garrison \& Arbaugh, 2007) 
Social presence is defined as the social and emotional connection among the learners and instructors in the learning environment (Cooper, Forino, Kanjanabootra, \& von Meding, 2020). The presence is categorised into affective expression, open communication and group cohesion (Garrison \& Arbaugh, 2007). Past researchers have extensively studied this element as it is one of the most powerful features in the CoI framework. Furthermore, social presence provides a safe environment for the learners to develop their self-confidence in constructing new knowledge (Li, 2015).

Teaching presence refers to the instructional design provided by the instructors in their efforts to facilitate knowledge construction among the learners (Garrison, 2016). This element consists of three parts, which include (1) instructional design and organisation, (2) facilitating discourse, and (3) direct instruction (Anderson, Rourke, Garrison, \& Archer, 2019). Furthermore, collaborative activities enable learners to have higher social presence and feel more incredible that a learning community has been created (Redmond \& Lock, 2006). Therefore, the instructors could integrate inquiry-based learning (teaching presence) into the CoI framework to enhance social connection between learners and instructors (social presence) alongside the efforts to ensure new knowledge can be constructed effectively (cognitive presence).

Based on the past research, Shea and Bidjerano (2010) propose a positive relationship between the three elements in the CoI framework (Figure 2). Past research shows that teaching and social presences have a positive impact on the cognitive presence. The teaching presence via the instructional design play a central role in directly affecting the perception on the social and cognitive presences, which are important to achieve the intended learning outcomes and to maintain a positive learning environment (Garrison, Cleveland-Innes, \& Fung, 2010).

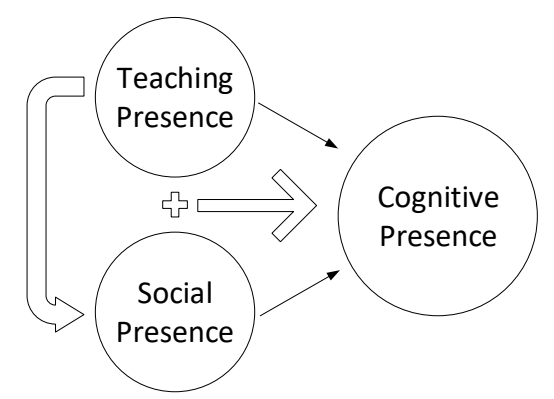

Figure 2. Relationship between elements in Community of Inquiry framework (Shea \& Bidjerano, 2010)

Project-based learning (PjBL) is an effective pedagogy that integrates real-life application. The project is commonly defined with several key features, including it is a realistic or real-world project requires critical thinking and problem solving (Uziak, 2016). It has explicit objectives with individual and collective learning, and the project needs to be completed in a given time frame. The PjBL is always grounded with student-directed learning with instructor as facilitator to scaffold, motivate and monitor the progress (Bell, 2010). Since the PjBL is conducted in a team setup, it requires students work collaboratively with their teammates in achieving shard goals. The students need to communicate and interact with their teammates due to the interdependency of the project.

The PjBL is an instructional design (teaching presence) to promote cooperatively support having the students in team to (social presence) the cognitive presence in the $\mathrm{CoI}$ framework for enhancing learning experiences.

\section{Problem}

Life Cycle Assessment (LCA) is a core course for the Master of Sustainable Systems degree in the MalaysiaJapan International Institute of Technology (MJIIT), Universiti Teknologi Malaysia. Students who enrol in the programme have diverse educational backgrounds, such as engineers, environmentalists, architects, biologists, and chemists. The course requires students to understand the fundamental concepts of LCA. The course expects students to perform all steps in an LCA using appropriate software after completing the course. In the 2020/2021 academic session, there were 13 students enrolled in the course, including five international and eight local students. There were five males and eight females in the class. The course learning outcomes were listed as follows:

- CLO1: Simulate an LCA study, understand its strengths, weaknesses, and appropriate use (assessments: assignments, tests)

- CLO2: Evaluate environmental impacts of a product, technology, or system by applying the LCA methodology (assessments: assignments, tests)

- CLO3: Perform an LCA on a system using publicly available data and software (assessments: project reports, presentations)

In previous semesters, the instructors conducted the course using student-centred learning through book-end lectures (Smith, 2000). It was observed that the steps to perform LCA using the LCA framework (Figure 3) are highly interdependent (Pryshlakivsky \& Searcy, 2013), which some content in the weekly classes seemed to be redundant. The teaching and learning became less effective when the theory component was explained with simplistic examples or simplistic manual calculations. In addition, the application of the LCA methodology (project) was superficial. Students completed the project with minimal guidance using demo-version of a commercial LCA software, namely OpenLCA software.

In the 2020/2021 academic session, the course was forced to adopt a complete virtual learning mode due to national lockdown during the COVID-19 pandemic. Hence, incorporating the CoI framework with PjBL aimed to enable students to undergo an effective teaching and learning process. 


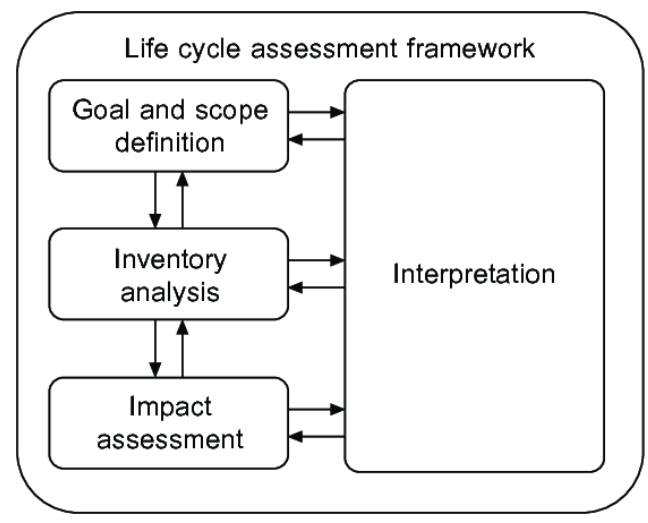

Figure 3. LCA framework (Pryshlakivsky \& Searcy, 2013)

\section{Design and Implementation}

The course was restructured for effective content delivery. The course curriculum was divided into the theoretical component (6 weeks) and project (application) (8 weeks) component, as shown in Table 1.

The theoretical component covered the environmental management systems (EMS), roles of LCA in EMS, international standards in LCA, terms and concepts in LCA, steps in the LCA framework. These virtual classes were conducted based on the book-end approach to ensure that learners paid attention during the classes. In this component, the learners were given tasks for step-by-step analysing published LCA case studies based on learners' interests. For every LCA step, the learners analysed how the literature case studies were conducted, and they present their findings in the virtual class. These tasks aimed to ensure that learners can learn all the LCA steps by analysing case studies and various examples on their efforts and by listening to explanations from their peers.

The lectures also focused on cooperative projectbased learning. The learners were divided into teams with 3 to 4 members, and each team was required to conduct a comparative LCA study for a selected product or process. The problem was designed to be open-ended. The learners can freely choose their teammates and select any topic that they were interested in based on their previous educational background or working experiences. For example, the environmental impacts of producing $1 \mathrm{MW}$ of electricity from renewable energy generation routes (solar PV, biomass and biogas) are studied from cradle to crave. The project was divided into three parts: comparative LCA's goal and scope (Phase 1 teamwork), LCA analysis (Phase 2- individual work) and comparison (Phase 3 - teamwork).

In Phase 1 of the project, each team discussed the product to be studied, which the differences in the individual scope for each member should be identified.

Table 1. Brief instructional design for LCA subject

\begin{tabular}{|c|}
\hline Week 1-6 (Theoretical Component) \\
\hline $\begin{array}{l}\text { - The virtual online classes are conducted with active learning approaches. } \\
\text { - Learners are given tasks to analyse selected literature case studies based on the goal and scope, inventory } \\
\text { analysis, impact assessment and the interpretation presented. } \\
\text { - Learners present their analysis findings, while peers learn from the case study of the presenters. } \\
\text { - Learners are required to install and learn an open-source LCA software using examples provided by the } \\
\text { software developers. Instructors monitor each student's progress every week. }\end{array}$ \\
\hline Week 7-8 (Project Component - Phase 1 - Project Conception) \\
\hline $\begin{array}{l}\text { The learners are grouped into teams with } 3 \text { to } 4 \text { members. The team autonomously decides the product or } \\
\text { process to be investigated as a comparative LCA study. The team must set shared goals and scopes for the } \\
\text { comparative study, with a similar process boundary and goal but using different process routes or raw } \\
\text { materials or products. } \\
\text { - Each member in the team is assigned with one scope for performing the LCA study, which later could be } \\
\text { compared. } \\
\text { - Outcomes of each team are presented. Each presentation receives impromptu feedback from the instructors. }\end{array}$ \\
\hline Week 9-12 (Project Component - Phase 2 - Individual LCA) \\
\hline $\begin{array}{l}\text { - Learners must use the open-source LCA software to perform individual LCA studies for the assigned scope. } \\
\text { Individual progress is presented, and students receive feedback from the instructors to ensure that the } \\
\text { teammates' assumptions are aligned. All learners are required to submit a report describing the results of the } \\
\text { individual LCA studies. } \\
\text { - To ensure the LCA studies are comparable, the members must have the same assumptions for their study. } \\
\text { Therefore, the learners must communicate with their teammates. }\end{array}$ \\
\hline Week 13-14 (Project Component - Phase 3 - Comparative LCA) \\
\hline $\begin{array}{l}\text { - Learners gather as a team and compare the results between individual scopes. } \\
\text { - The team is requested to submit a report comparing the environmental impacts of the processes for the sa }\end{array}$ \\
\hline
\end{tabular}


The problem definition, functional unit, system boundary, impact categories and assumptions were harmonised among team members to ensure the LCA studies will be comparable. Subsequently, each team member was assigned one of the scopes, and he/she was required to perform an individual LCA study. An example is given as follows: the overall team's scope was setup to produce the same amount of product (functional unit), for instance $1 \mathrm{MW}$ of electricity production. Next, student A took the scope of studying the environmental impacts of producing $1 \mathrm{MW}$ of electricity from solar PV, while student B studied on generation from biomass, and student $\mathrm{C}$ studied for electricity generation from biogas. Without setting the problem correctly, the team could not complete Project Phase 3 in a team. A team presentation session was arranged to provide facilitation and feedback to the learners, which the learners had opportunities to learn from other teams.

Once the problem identification was made in the team, the individual learners were expected to perform an LCA study using open-source LCA software in phase 2. The learners were expected to further discuss in the team to refine the problem and assumptions as a comparable study had to be done. A progress presentation was conducted in the project duration to ensure that the learners worked as planned and instructors' feedback was provided on time. In other weekly class hours, the instructors met with all learners to listen to their progress and provided feedback. The team members needed to ensure synchronisation in their work within the team. During the presentation or progress meetings, instructors took opportunities to link the project to the theories and ensured learners master the theories through examples. Lastly, the learners were expected to produce an individual report to demonstrate their mastery of the LCA steps and software.

This individual project phase ensured individual accountability and for learners to achieve targeted learning outcomes. In addition, this project phase was designed to connect the teammates to form a social presence. The learners had to consult their team members, who face similar difficulties due to solving a similar problem, promoting interdependence between team members.

In the last phase of the project (Phase 3), the learners gathered to compare each member's results. As a continuation of previous example given, the environmental impacts due electricity generating from different renewable energy sources (e.g., solar versus biomass versus biogas) were compared. Each member presented the impacts for one type of energy source in Phase 2 and at the same time, they listened presentations of other types of energy source. This phase helped learners deepen their understanding of their own work and appreciate the different scopes completed by the team members. In addition, at this stage, the learners were expected to appreciate the importance of teamwork.

Besides that, the instructors were active in the learning management system in providing various resources to the learners (synchronous learning). Meanwhile, the instructors initiated an open discussion group using an online messaging application (i.e., WhatsApp). The learners were encouraged to ask questions on the LCA concept or software in the group. Classmates were encouraged to help their classmates before the instructors intervened on the same questions.

A questionnaire which aimed to explore student perceptions on the course was distributed to the students via Google Form after the course completion. Eleven students (85\% response rate) answered the questionnaire. They consented to publish the results and understood perseverance of the anonymity.

The questionnaire consisted of six Likert-scale questions and six open-ended questions. The Likertscale questions were modified from a validated instrument in measuring student perceptions of an educational environment (Roff et al., 1997). The original instrument was validated and used in different countries (Miles, Swift, \& Leinster, 2012). The six questions asked were: (1) Discussions in WhatsApp helps to develop my competence, (2) Working in groups - having group members to seek help from or to exchange ideas, helps to develop my competence, (3) Weekly consultations with lecturers helps to develop my competence, (4) A project solving a real industrial problem, helps to develop my competence, (5) Individual assessment (report) helps to develop my competence. Each question had 5 scales ranged from 1 (strongly disagree), 2 (disagree), 3 (unsure), 4 (agree) to 5 (strongly disagree).

Meanwhile, for each Liker-scale question, a corresponding open-ended question was created to allow students to elicit their rationales for the Likertscale responses. The open-ended questions were designed using hypothetical questions (Merriam \& Tisdell, 2015). An open-ended question should be designed to obtain an explanation and avoid imposing ideas on the respondents (Merriam \& Tisdell, 2015). An example of an open-ended question was, "If you were the lecturer, would you arrange to work in groups again for next semester? Why? Please elaborate and give examples."

\section{Results and Discussion}

The course with new delivery methods was successfully implemented. The student overall achievement of the previous $(n=5)$ and current $(n=13)$ semesters has improved from 76 marks to 80 marks. One student may be seen as an outlier for not achieving the targeted overall attainment level; he had issues accessing the online learning environment during the COVID-19 pandemic. 
Table 2. Students feedback on various features in the project-based community of inquiry

\begin{tabular}{|c|c|}
\hline \multicolumn{2}{|c|}{ Real-life Project (Cognitive Presence) } \\
\hline $\begin{array}{l}\text { "A project solving a real } \\
\text { industrial problem, } \\
\text { helps to develop my } \\
\text { competence." }\end{array}$ & $\begin{array}{l}\text { - "It is interesting to learn and gain new skills as well as exposing students to the rea } \\
\text { - "It problems." } \\
\text { - "First of all, it was fun. Since it's a real scale project, I always felt connected with the } \\
\end{array}$ \\
\hline $\begin{array}{l}\text { Strongly agree: } 91 \% \\
\text { Unsure: } 9 \%\end{array}$ & $\begin{array}{l}\text { time. Secondly, it was a new experience to learn new software. So definitely, these } \\
\text { two (methods) meant a lot." }\end{array}$ \\
\hline
\end{tabular}

\section{Project - Individual LCA Phase (Cognitive Presence)}

"Individual assessment (report) helps to develop my competence."

Strongly agree: $64 \%$ Agree: $36 \%$

- "Through the individual reports, the whole idea of an LCA study became very clear. Since an individual did all the tasks in the individual report, this makes a clear-cut idea for all about their respective topic."

- "(Individual report) assesses the student individually and find out who did not do the work. Group projects might benefit the incompetent members while other people did most of the work. An individual assessment can ensure the fairness of marks given."

\section{Project - Comparative LCA Phase (Cognitive Presence)}

"Group assessment (report) helps to develop my competence."

Strongly agree: $82 \%$ Agree: 18\%
- "The result comparison for the group report seemed good and also very technical. Through the group report, we learnt how a comparative LCA looks like and what parameters should be looked for during the result discussion, simulation and analysis."

- "We can share our knowledge within the group. Moreover, I agree with the proportion of group and individual works in this semester LCA."

- "It helps each member to share and solve the problem together."

\section{Whatsapp Group (Social Presence)}

\begin{tabular}{l|l} 
"Discussions in & $\bullet$ \\
WhatsApp helps to & \\
develop my competence."
\end{tabular}

Strongly agree: $55 \%$

Agree: $27 \%$

Unsure: $18 \%$ "It's a convenient way to do so since physical classes are not available. The information needed can be spread faster."

- "I would promote discussion in WhatsApp since this is the fastest route to reach the lecturers. Other than that, instructors provide speedy responses anytime we encounter problems during our time doing assignments."

- "Some issue brought up by other classmates, and the discussion may help to clear some doubts for other classmates."

- "It promotes communication between students, especially when one encountered a problem, and another has encountered and managed to solve the same problem."

\section{Team-based learning (Social Presence)}

"Working in groups having group members to seek help from or to exchange ideas, helps to develop my competence."

Strongly agree: $64 \%$ Agree: $36 \%$

- "Sometimes it is easier and comfortable to discuss some topics in a small group."

- "Group work was the best idea. Because students would not feel pressurised with the new subject and always has someone to discuss further. I liked the group work theme. For this, the in-depth knowledge gain was possible."

- "Working in groups prompt discussion within the group. Students who are shy to discuss in WhatsApp group (with instructors) can discuss within their members, and the discussion will be more related to the chosen topic."

- "It allows the sharing of information from different perspectives of certain topics from the group members. Since the group members are from various backgrounds, different inputs are obtained through the discussion done. The experiences and perspectives enable more interesting topics to be discussed and broaden the inputs."

\section{Weekly Consultation with Instructor (Teaching Presence)}

"Weekly consultations with lecturers help to develop my competence."

Strongly agree: $64 \%$ Agree: $36 \%$
- "Sometimes we don't know if what we're doing is correct, so with the weekly consultation, at least we can consult midway our progress (whether) is correct or not."

- "Weekly consultations help students to keep on track as well as helping them to (have) more understanding on the topic."

- "The weekly consultations seemed very effective towards clearing our thought. For example, every homework had been discussed quite precisely during the classes. It was a very nice idea, I must say. 
Student responses in the questionnaire were analysed and shown in Table 2 . The results were matched to the cognitive, social and teaching presences in the CoI framework. The majority of the students agreed that the newly introduced delivery methods had improved their learning experience in the course.

The open-ended industrial project, individual project report on individual LCA study and team project report on comparative LCA study were evidence of cognitive presence (Table 3). The students appreciated these methods for supporting their learning. The students concluded that the industryrelated project facilitates them to master the LCA method better and prepared them for actual usage of the LCA methodology in the future. Meanwhile, the individual project was well accepted by all students because it helped ensure all individual students could master the subject matter. The individual assessment differentiated the competency and contribution of every team member in the project. Lastly, the students highly recognised the project team report/assessment, which technically exposed the students to an additional concept: the comparative LCA. The team analysed the results from individual LCA in this part, which helped the students to understand parameters to be compared. Although online learning was known to have a lower commitment from the students, the students agreed that the team project formed a supporting system among the team members throughout the learning process.

The open discussion group using WhatsApp and team-based learning were planned to promote social presence in the course. Some students affirmed that the active use of the open discussion group in WhatsApp helped their learning process through impromptu discussion with classmates and guidance from the instructors. Findings of this study echo past research (Qamar, Riyadi, \& Wulandari, 2019) that WhatsApp discussions help promote interactions between the students. Universities unofficially adopt WhatsApp, yet it is user friendly to students (Mpungose, 2020). On the other hand, some students may not appreciate the use of the open discussion group, as they believed that face-to-face interaction will be more effective than the online platform. Next, most students felt that team-based learning is helpful. This was because the team members were helping each other in solving technical issues in the software. Moreover, as students were from mixed educational backgrounds, team-based activities during synchronous sessions were given additional credit for the reason it allowed the students to learn knowledge from different fields of study.

Lastly, the teaching presence was a critical element in the CoI framework for effective online learning. The instructors needed to design and support the learning experiences for the students. The students provided positive comments that the instructional design embedded with project-based learning has supported their learning process. In addition, students appreciated the instructor's impromptu feedback in the online discussion group. Moreover, the weekly consultation took place during synchronous learning classes was believed to help the students understand and progress in their assignments and project through just-in-time feedback. Effective feedback has characteristics of being relevant, immediate, factual, helpful, respectful, tailored and encouraging (Ovando, 1994).

\section{Conclusion}

Using the CoI framework for an online postgraduate course can improve student achievement and learning experiences during the COVID-19 pandemic. Project-based learning complements the CoI framework in creating proper teaching presence to achieve the cognitive presence while encouraging social presence in the virtual classroom environment.

This study is imperfect. Future implementation of the LCA course may consider using self and peer assessments (Foong \& Liew, 2020) or reflection journals (Boud, Keogh, \& Walker, 2013) to avoid freeriding among the team members, and help them reflect their attitudes with the aim to further improve their engagement throughout the course.

\section{References}

Adnan, M., \& Anwar, K. (2020). Online Learning amid the COVID19 Pandemic: Students' Perspectives. Online Submission, 2(1), 45-51.

Anderson, T., Rourke, L., Garrison, R., \& Archer, W. (2019). Assessing Teaching Presence in a Computer Conferencing Context. Online Learning, 5(2). doi:10.24059/olj.v5i2.1875

Arbaugh, J. B., Bangert, A., \& Cleveland-Innes, M. (2010). Subject matter effects and the Community of Inquiry (CoI) framework: An exploratory study. The Internet and Higher Education, 13(1), 37-44. doi:https://doi.org/10.1016/j.iheduc.2009.10.006

Bell, S. (2010). Project-Based Learning for the 21st Century: Skills for the Future. The Clearing House: A Journal of Educational Strategies, Issues and Ideas, 83(2), 39-43. doi:10.1080/00098650903505415

Boud, D., Keogh, R., \& Walker, D. (2013). Reflection: Turning experience into learning: Routledge.

Chakraborty, P., Mittal, P., Gupta, M. S., Yadav, S., \& Arora, A. (2021). Opinion of students on online education during the COVID-19 pandemic. Human Behavior and Emerging $\begin{array}{lll}\text { Technologies, 3(3), 357-365. } & \text {. }\end{array}$ doi:https://doi.org/10.1002/hbe2.240

Cooper, V. A., Forino, G., Kanjanabootra, S., \& von Meding, J. (2020). Leveraging the community of inquiry framework to support web-based simulations in disaster studies. The Internet and Higher Education, 47, 100757. doi:https://doi.org/10.1016/j.iheduc.2020.100757

Foong, C. C., \& Liew, P. Y. (2020). Investigating the Reliability and Usefulness of Self- and Peer Assessments of a Capstone Design Project. International Journal of Engineering Education, 36(6), 1850-1861.

Garrison, D. R. (2016). E-learning in the 21st century: A community of inquiry framework for research and practice: Taylor \& Francis.

Garrison, D. R., Anderson, T., \& Archer, W. (1999). Critical Inquiry in a Text-Based Environment: Computer Conferencing in Higher Education. The Internet and Higher Education, 2(2), 87-105. doi:https://doi.org/10.1016/S1096-7516(00)00016-6 
Garrison, D. R., \& Arbaugh, J. B. (2007). Researching the community of inquiry framework: Review, issues, and future directions. The Internet and Higher Education, $10(3)$,

157-172. doi:https://doi.org/10.1016/j.iheduc.2007.04.001

Garrison, D. R., Cleveland-Innes, M., \& Fung, T. S. (2010). Exploring causal relationships among teaching, cognitive and social presence: Student perceptions of the community of inquiry framework. The Internet and Higher Education, 13(1), 31-36. doi:https://doi.org/10.1016/j.iheduc.2009.10.002

Li, K. M. (2015). Learning styles and perceptions of student teachers of computer-supported collaborative learning strategy using wikis. Australasian Journal of Educational Technology, 31(1).

Merriam, S. B., \& Tisdell, E. J. (2015). Qualitative research: A guide to design and implementation: John Wiley \& Sons.

Miles, S., Swift, L., \& Leinster, S. J. (2012). The Dundee Ready Education Environment Measure (DREEM): a review of its adoption and use. Medical Teacher, 34(9), e620-e634.

Mishra, L., Gupta, T., \& Shree, A. (2020). Online teaching-learning in higher education during lockdown period of COVID-19 pandemic. International Journal of Educational Research Open, 1 , 100012. doi:https://doi.org/10.1016/j.ijedro.2020.100012

Mpungose, C. B. (2020). Emergent transition from face-to-face to online learning in a South African University in the context of the Coronavirus pandemic. Humanities and Social Sciences Communications, 7(1), 113. doi:10.1057/s41599-020-00603-x

Ovando, M. N. (1994). Constructive feedback: A key to successful teaching and learning. International Journal of Educational Management.
Pryshlakivsky, J., \& Searcy, C. (2013). Fifteen years of ISO 14040 : a review. Journal of Cleaner Production, 57, 115-123.

Qamar, K., Riyadi, S., \& Wulandari, T. (2019). Utilization of whatsapp application as discussion media in blended learning. Journal of Education and Learning (EduLearn), 13, 370-378. doi:10.11591/edulearn.v13i3.8412

Redmond, P., \& Lock, J. V. (2006). A flexible framework for online collaborative learning. The Internet and Higher Education, 9(4), 267-276. doi:https://doi.org/10.1016/i.iheduc.2006.08.003

Roff, S., McAleer, S., Harden, R. M., Al-Qahtani, M., Ahmed, A. U., Deza, H., . . . Primparyon, P. (1997). Development and validation of the Dundee ready education environment measure (DREEM). Medical Teacher, 19(4), 295-299.

Shea, P., \& Bidjerano, T. (2010). Learning presence: Towards a theory of self-efficacy, self-regulation, and the development of a communities of inquiry in online and blended learning environments. Computers \& Education, 55(4),

1721-1731. doi:https://doi.org/10.1016/i.compedu.2010.07.017

Smith, K. A. (2000). Going Deeper: Formal Small-Group Learning in Large Classes. New Directions for Teaching and Learning, 2000(81), 25-46. doi:https://doi.org/10.1002/tl.8103

Stewart, M. K. (2019). The Community of Inquiry Survey: An Assessment Instrument for Online Writing Courses. Computers and Composition, 52, 37-52. doi:https://doi.org/10.1016/j.compcom.2019.01.001

Uziak, J. (2016). A project-based learning approach in an engineering curriculum. Global Journal of Engineering Education, 18(2), 119-123. 